\title{
The influence of supervision, task commitment and job satisfaction on Organizational Citizenship Behavior (OCB) of training alumni
}

\author{
Enong Rostiawati ${ }^{1}$, Suryadi $^{2}$, Ma'ruf Akbar ${ }^{3}$ \\ \{difasrostiawati@gmail.com ${ }^{1}$, Makrufakbar@unj.ac.id ${ }^{3}$ \} \\ Universitas Negeri Jakarta, Indonesia
}

\begin{abstract}
Abstact. Organizational Citizenship Behavior (OCB) is an aspect that can be influenced by supervision, task commitment and job satisfaction. This study aims to determine how these variables actually affect the OCB of training alumni in Banten Province. Also, this study uses a quantitative approach through survey methods. The samples are comprised of 80 respondents, and the results of analysts and the interpretation of the data are as follows: (1) Supervision has a positive direct effect on training alumni OCB at 0.569 , meaning that improvement in supervision will result in an increase in the OCB of training alumni; (2) Commitment assignments have a positive direct effect amounting to 0.681, therefore improvement in task commitment results in an advancement ; (3) Job satisfaction has a positive direct effect at 0.839 , meaning that improvement in job satisfaction would lead to enhanced training alumni; (4) Supervision has a positive direct effect on job satisfaction at 0.660 , meaning that supervising improvements have resulted in increased job satisfaction; (5) Commitment assignments have a positive direct effect on job satisfaction at 0.674 , meaning that the improvement of task commitment results in an increase in job satisfaction for them as well. Thus, the OCB training activities of alumni can be achieved through good supervision, maximizing task commitment to employees, and conducting OCB research with other variables, so that objective and comprehensive research can be obtained.
\end{abstract}

Keywords: Supervision, Task Commitment, Job Satisfaction, Organizational Citizenship Behaviour

\section{Introduction}

Human resources in the provincial government of Banten are civil servants and non civil servants. Civil servants are considered CS civil servants who have a vital role in running the government. Considering that they play an important role, it is appropriate for the organization to 
carry out a mechanism to maintain human resources by paying attention to the OCB CV itself. (Moorhead.2014) OCB refers to behavior of individuals who a positive overall contribution to the organization.OCB refers to individual behavior that has a positive impact on the organization.OCB for CS is a manifestation of job satisfaction because it can be described as a feeling of satisfaction or pleasure in the work to be done [1]. (John W. Newstrom and Keith Davis, 2002) report that high employee job satisfaction signals that the organization is well managed and fundamentally produces effective management behavior.[2]. Empirical data on OCB problems from Echelon IV PNS training alumni in Banten Province are influenced by five factors, namely: 1) employee behavior in work that does not increase the interest of others by 35\%;2) accuracy in employment is still low at $68 \%$; 3) $78 \%$ contribution to organizational problems; 4) sportsmanship at the workplace at $84 \%$. Based on the description above, researchers are interested in investigating the research with the title "The Effect of Supervision, Task Commitment and Job Satisfaction on Organizational Citizenship Behavior (OCB) Alumni Training from IV Echelon Officials of Civil Servants in Banten Province."

\section{Formulation of the Problem}

This study about the effect of supervision on the Organizational Citizenship Behavior of training alumni of Echelon IV Civil Servants in Banten Province can be formulated as follows:

1. Is there a direct effect of supervision?

2. Is there a direct effect of task commitment?

3. Is there a direct effect of job satisfaction?

4. Is there a direct effect of supervision?

5. Is there a direct effect of task commitment?

\section{Theoretical Framework}

\subsection{Organizational Citizenship Behavior (OCB)}

(Glinow.2010) Organizational citizenship behavior (OCB) is various forms of cooperation and helpfulness to others that support the organization's social and psychlogical context. [3].(Nelson and Quick.2006) OCB as is behavior that is above and beyond the call of duty." [4].(Luthans. 2011) explains the dimensions of OCB, namely: (1) altruism, selfless concern for fellow coworkers; (2) conscientiousness, refers to impersonal behavior that shows caution, extreme care and great effort, for example: to offer additional work even when the work is completed; (3) civic virtue, to work voluntarily ; (4) sportsmanship, to support each other in the team for organizational success; and (5) courtesy, understanding and empathy.[5]

\subsection{Supervision}


(Bailey.2006) Supervision is process of overseeing the ability of people to meet the goals of the organization in which they work.[6]. (Shohet, 2006 ) Supervision as: 'interpersonal interaction in an effort to make the latter more effective in helping people.[7].(Shafranske, 2004) Supervision is a professional activity collaborative interpersonal process. It involves observation, evaluation, feedback.[8]

\subsection{Task Commitment}

(Amstrong.2009) Commitment to the task is a state of being in which an individual becomes bound by his (sic) actions to beliefs that sustain his activities and his own involvement [9].(Glinow, 2008) task commitment is to refers to the employee's emotional attachment to, identification with, and involvement in a particular organization.[10].(Kinicki.2010.) Commitment is an agreement to do something foryourself, another individual, group, or organization.[11].(Miner, 2005.)Task Commitment is expected to relate to performance as a direct positive effect/[12].

\subsection{Job Satisfaction}

(Robbins.2003) the term job satisfaction refers to an individual's general attitude towards his or her job. A person with a high level of job satisfaction holds positive attitudes towards the job, while a person who is dissatisfied holds negative attitudes [13]. (Newstrom.2011) Job satisfaction is a set of favorable or unfavorable feelings and emotion. Job satisfaction is an affective attitude a feeling of relative like or dislike toward something"[14] (Gibson, Ivancevich. 2012) five Job satisfaction characteristics: (1) Pay; (2) Job; (3) Promotion opportunities; (4) Supervisor; (5) Coworkers.[15]

\section{Research Methodology}

This study used a quantitative approach through the survey method. It is a method of collecting data based on a survey whose source of data and main information are obtained from respondents as research samples. The analysis unit was Eselon IV Civil Servants who participated in level IV leadership training in Banten Province.

In this study, the population was training alumni of Echelon IV Civil Servants who have followed the leadership training of level IV in 2016 and 2017 which was a total of 80 respondents in Banten Province. This population is also a research sample, and is spread to forty three OPD in Banten Province.

To study the effect of supervision, task commitment, and job satisfaction on Organizational Citizenship Behavior (OCB), a questionnaire was used. The researcher used the validity and reliability test to examine whether or not the questionnaire was valid and reliable. The validity test of the questionnaire used was Statistic Product Moment. Meanwhile the reliability of the questionnaire was determined by using Alpha Cronbach. The result shows that the validity of the Organizational Citizenship Behavior of supervision, task commitment, and job satisfaction 
variables were valid and reliable. Furthermore, it can be inferred that the four instruments can be used in this study. (see at : https://osf.io/h9bw7/)

\section{Research Findings And Discussion}

\subsection{Data Description}

The measurement of this study will be based on independent (exogenous) and dependent variables (endogenous). Independent variables were whose variations were explained by exogenous variables. In this study, the endogenous variable was Organizational Citizenship Behavior $\left(\mathrm{X}_{4}\right)$. Meanwhile, the exogenous variables were those whose variation were assumed to have occurred not because of others from this model. In this study, the exogenous variables include supervision $\left(\mathrm{X}_{1}\right)$, task commitment $\left(\mathrm{X}_{2}\right)$ and job satisfaction $\left(\mathrm{X}_{3}\right)$. The summary of the endogenous and exogenous variable data can be seen in table 1

The results of the description of Organizational Citizenship Behavior (OCB) data, supervision, task commitment, and job satisfaction can be seen in tables 2,3,4 and 5 .

Most variable scores variabel of Organizational Citizenship Behavior are in the interval class between $130-139(32,50 \%)$ and followed by interval class $140-149(25,00 \%)$ and $120-129$ $(16,25 \%)$. Meanwhile, the lowest scores are in the range $160-169(2,50 \%)$. The frequency distribution of supervision can be seen in table 3 .

Most variable scores of supervision variable (X1) are in the interval class between $122-136$ (33.75\%) and followed by interval class $107-121(27.50 \%)$ and $137-151(11.25 \%)$. Meanwhile, the lowest scores are in the range $152-166(1.25 \%)$. The frequency distribution of task commitment can be seen in table 4. (see at :

Most variable scores of Task Commitment variable (X1) are in the interval class between 121 - $132(31.25 \%)$ and followed by interval class $133-144(18.75 \%)$ and $109-120(17,50 \%)$. Meanwhile, the lowest scores are in the range $97-108$ (5.00\%). The frequency distribution of job satisfaction can be seen in table 5 .

Most variable scores of Job satisfaction are in the interval class between $129-141$ (40.00\%) and followed by interval class $142-154(27.50 \%)$ and $116-128$ (18.75\%). Meanwhile, the lowest scores are in the range $77-89(1.25 \%)$.

\subsection{Testing Analysis Requirement}

\subsubsection{Data Normality Test}

For the estimated distribution normality error, the estimated error normality test was adopted using Lilefors (Lo). Based on the calculation of the test, the error results are represented in table 6

The results of the normality test of all pairs of research variables, namely supervision with OCB ( $\mathrm{Y}$ on $\mathrm{X} 1$ ), task commitment on OCB ( $\mathrm{Y}$ on $\mathrm{X} 2)$, job satisfaction on OCB ( $\mathrm{Y}$ on $\mathrm{X} 3$ ), 
supervision on job satisfaction (X3 on X1), and job satisfaction on task commitment (X3 on X2) show that they are all linear. This means that all relationships between variables are linear. The result of the linearity test of the regression model can be seen at table 7

\section{Hypothesis Testing}

Hypothesis testing was conducted using the parametic statistic of correlation of Pearson product moment.

The first hypothesis: from the results of the calculation of coefficient, the direct effect of supervision on $O C B\left(\mathrm{X}_{4}\right)$ was obtained, $\mathrm{p}_{41}=0,569$, $\mathrm{p}$-value $=0,000<0,005$, while the value of $t_{\text {count }}=6,107$ and the value of $t_{\text {table }}$ at significance level $\alpha(0,05)=3,98$ for $\mathrm{dk}=78$, because $t_{\text {count }}>$ $t_{t a b l e}$, so Ho is rejected and $\mathrm{H}_{1}$ is accepted. Thus, it can be inferred that supervision $\left(\mathrm{X}_{1}\right)$ has a direct positive effect on $O C B\left(\mathrm{X}_{4}\right)$. Meanwhile, from the determined coefficient from the table, it can be seen that $\mathrm{R}$ square $=0,323$, this means that $32.3 \%$ variation of $O C B$ can be explained by supervision.

The second hypothesis: from the results of the calculation of coefficient the direct effect of supervision towards $O C B\left(\mathrm{X}_{4}\right)$ was obtained, $\mathrm{p}_{42}=0,681$, $\mathrm{p}$-value $=0,000<0,005$, while the value of $\mathrm{t}_{\text {count }}=8,220$ and the value of $\mathrm{t}_{\text {table }}$ at significance level $\alpha(0,05)=3,98$ for $\mathrm{dk}=78$, because $t_{\text {count }}>t_{\text {table, }}$ so Ho is rejected and $H_{1}$ is accepted. Thus, it can be inferred that task commitment $\left(\mathrm{X}_{2}\right)$ has a direct positive effect on $O C B\left(\mathrm{X}_{4}\right)$. Meanwhile, from the determined coefficient from the table, it can be seen that $\mathrm{R}$ square $=0,464$, and this means that $46.4 \%$ variation of $O C B$ can be explained by task commitment.

The third hypothesis:. from the results of the calculation of coefficient, the direct effect of supervision on $O C B\left(\mathrm{X}_{4}\right)$ was obtained, $\mathrm{p}_{43}=0,839$, $\mathrm{p}$-value $=0,000<0,005$, while the value of $t_{\text {count }}=13,600$ and the value of $t_{\text {table }}$ at significance level $\alpha(0,05)=3,98$ for $\mathrm{dk}=78$, because $t_{\text {count }}>$ $t_{\text {table }}$ so $H o$ is rejected and $H_{1}$ is accepted. Thus, it can be inferred that job satisfaction $\left(\mathrm{X}_{3}\right)$ has a direct positive effect on $O C B\left(\mathrm{X}_{4}\right)$. Meanwhile, from the determined coefficient from the table, it can be seen that $\mathrm{R}$ square $=0,703$, and this means that $70.3 \%$ variation of $O C B$ can be explained by job satisfaction.

The fourth hypothesis: from the results of the calculation of coefficient, the direct effect of supervision $\left(\mathrm{X}_{1}\right)$ on job satisfaction $\left(\mathrm{X}_{3}\right)$ as obtained, $\mathrm{p}_{31}=0,660$, $\mathrm{p}$-value $=0,000<0,005$, while the value of $\mathrm{t}_{\text {count }}=7,762$ and the value of $\mathrm{t}_{\text {table }}$ at significance level $\alpha(0,05)=3,98$ for $\mathrm{dk}=78$, because $t_{\text {count }}>t_{\text {table }}$, so Ho is rejected and $\mathrm{H}_{1}$ is accepted. Thus, it can be inferred that supervision $\left(\mathrm{X}_{1}\right)$ has a direct positive effect on job satisfaction $\left(\mathrm{X}_{3}\right)$. Meanwhile, from the determined coefficient from the table, it can be seen that $R$ square $=0,436$, this means that $43,6 \%$ variation of job satisfaction can be explained by supervision.

The fifth hypothesis: from the results of the calculation of coefficient, the direct effect of supervision $\left(\mathrm{X}_{1}\right)$ on task commitment $\left(\mathrm{X}_{2}\right)$ was obtained, $\mathrm{p}_{32}=0,674$, $\mathrm{p}$-value $=0,000<0,005$, while the value of $t_{\text {count }}=8,066$ and the value of $t_{\text {table }}$ at significance level $\alpha(0,05)=3,98$ for $\mathrm{dk}=$ 78 , because $t_{\text {count }}>t_{\text {table, }}$ so Ho is rejected and $\mathrm{H}_{1}$ is accepted. Thus, it can be inferred that task commitment $\left(\mathrm{X}_{2}\right)$ has a direct positive effect on job satisfaction $\left(\mathrm{X}_{3}\right)$. Meanwhile, from the determined coefficient from the table, it can be seen that $\mathrm{R}$ square $=0,455$, this means that $45,5 \%$ variation of job satisfaction can be explained by task commit

\section{Conclusions}


Supervision, task commitment, job satisfaction has a direct positive effect towards Organizational Citizenship Behavior of training alumni of Echelon IV Civil Servants in Banten Province. Organizational Citizenship Behavior alumni diklat pegawai PNS Eselon IV can be achieved through good supervision, maximizing task commitment to employees, and conducting Organizational Citizenship Behavior (OCB) research with other variables, so that objective and comprehensive research can be obtained

\section{References}

[1] Ricky W. Griffin and Gregory Moorhead, Organizational Behavior, Managing People and Organizations.Australia: South Western. (2014)

[2] John W. Newstrom,Keith Davis, Organizational Behavior, Human Behavior at Work. (Irwin: McGraw-Hill, (2002)

[3] McShane, Steven L. and Marry Ann Von Glinow, Organizational Behavior. Boston: McGrawHill. (2010)

[4] Debra L. Nelson and James Campbell Quick, Organizational Behavior: Foundation, Realities and Challenges, $5^{\text {th }}$ Edition (Australia: Thomson, 2006), h.123.

[5] Fred Luthans, Organizational Behavior, An Evidence-Based Approach.New York: McGrawHill. (2011)

[6] Kathleen M.Bailey, Language Teacher Supervision. New York: Cambridge University Press (2006)

[7] Peter Hawkins and Robin Shohet..Supervision In Th helping Professions.USA: McGrawHill.(2006)

[8] Carol A. Falender and Edward P. Shafranske, Clinical Supervision, A Competency-Based Approach USA: American Psychological Assosiation. (2004)

[9] Michael Amstrong, Amstrong's Handbook of Human Resource Management Practice.London: Kogan Page (2009)

[10] Mc Shane dan Von Glinow.Organizational Behavior:Emerging Realities for the Work Place Revolution.New York: McGraw Hill.( 2008)

[11] Robert Kreitner and Angelo Kinicki, Organizational Bahavior.Boston: McGraw-Hill.(2010)

[12] John B. Miner, Organizational Behavior Essential Theories of Motivation and Leadership .New York: M.E. Sharpe, Inc.(2005)

[13] Stephen Robbins,Essentials of Organization Behavior.NewJersey : Pearson Education, Inc, $(2003)$

[14] Jhon W. Newstorm, Organizational Behavior, Human Behavior at Work.Boston: McGrawHill. (2011)

[15] James L.Gibson, Jhon M. Ivancevich, James H.Donnelly and Robert Konopaske,

Organization : Behavior, Structure, Processes.New York: McGraw-Hill. (2012) 